\title{
POOL OF FUNDS APPROACH AND ASSET ALLOCATION APPROACH IN SHARIA'S PERSPECTIVE (A Literature Review)
}

\author{
Fahmi Ali Hudaefi \\ Alumni STEI SEBI \\ \& \\ Ahmad Bisyri \\ Dosen STEI SEBI
}

\begin{abstract}
The aim of this research is to explore the Islamic perspective on the conventional thought of funds banking allocation methods, they are asset allocation approach and pool of funds approach, which one of them is practiced in Islamic banking in Indonesia, it is pool of funds approach. Sharia instruments that used to explore Islamic perspective on those two conventional methods are the verses of Islamic values in transaction, they are doing amanah in muamalah as taught in An-Nisa 68, being identified the owned property as taught in Al-Baqarah 188, doing a better notation in muamalah as taught in Al-Baqarah 283 and being fair in fulfilling weight and measure as taught in Hud 85. Other used sharia instruments are history of Prophet Muhammad pbuh and Caliph Umar bin Abdul Aziz and Fiqh special axiom in muamalah. This descriptive qualitative research with the method of content analysis data finds that the asset allocation approach is more agreeable method to all sharia instruments that used in this research.
\end{abstract}

Keywords: Al-Qur'an, Tafser, Islamic Values in Muamalah, Islamic Bank Principal, Bank Fund Allocation Methods

\begin{abstract}
Abstrak
Penilitian ini berujuan untuk mengetahui pandangan syariah terhadap metode alokasi dana bank yang berasal dari pemikiran konvensional, yaitu pool of funds approach dan asset allocation approach, dimana pool of funds approach dipraktikan di perbankan syariah Indonesia. Instrumen syariah yang digunakan dalam penelitian ini atau yang menjadi tolak ukur pandangan syariah terhadap kedua metode tersebut adalah nilai-nilai Islam dalam bermuamalah yang terkandung di dalam Al-Qur'an, yaitu berlaku amanah di dalam surat An-Nisa 58, jelasnya sumber kepemilikan harta didalam surat Al-Baqarah 188, melakukan pencatatan yang baik didalam muamalah dalam surat Al-Baqarah 283 dan berlaku adil dalam memenuhi takaran dan timbangan didalam surat Hud 85. Instrumen syariah lainnya yang digunakan adalah sejarah keuangan yang ada hubungannya dengan sistem pengalokasian dana pada zaman Nabi Muhammad Saw dan Khalifah Umar bin Abdul Aziz, serta Kaidah Khusus Fiqh di bidang muamalah. Penelitian dekriptif dengan pendekatan kualitatif dan content analysis sebagai alat analisis data menunjukan bahwa metode asset allocation approach lebih sesuai
\end{abstract}


dengan nilai-nilai syariah yang terdapat di dalam instrument-instrumen syariah yang menjadi tolak ukur di dalam penelitian ini.

Kata Kunci: Al-Qur'an, Tafsir, Nilai Islam dalam Bermuamalah, Prinsip Orepasional Bank Syariah, Metode Alokasi Dana Bank

\section{Introduction}

Islamic bank has been about 30 years operated in the global scale, the supervising of sharia values was developed and improved continuously (DeLorenzo, 2004, p. 32). Both conventional and Islamic banks surely have to face the liquidity risk (Pratiwi, 2013). In managing liquidity, Islamic bank has a different way from the conventional's one. Therefore, Islamic bank should construct the liquidity management programs as its risk nature, characteristics and should be based on sharia values (Ismal, 2010, p.60).

Islamic bank has a specific aspect in the ways of its funding and lending systems. So, the balance sheet structure of Islamic bank is totally different from the conventional bank's one (Obaidullah \& Wilson, 2005, p. 19). The future of Islamic banks will depend on their abilities to manage their different risks (Khan \& Ahmed, 2001, p. 22). One of the different and unique risks that Islamic Bank has is sharia compliance risk (Thijs, 2010, p. 14).

Managing liquidity to banks is a main job. The fact that many used instruments in managing liquidity are based on interest rate, it becomes more challenging to do that job for Islamic Banks (Ariffin, 2012, p. 68). Fail managing liquidity not only will lead to a bankrupt, but also will lead to a global crisis (Bhattacharya \& Jacklin, 1988).

Theoretically, according to Siamat (2005a, p. 325-326) a bank should lend its funds to a fixed asset while it is also should notice the liquidity and the safety of the asset. Because bank's liability is paid by cash, a liquid instrument is the main asset for the necessity of liquidity needs. For example in the investment, the asset that can be quickly converted to a liquid asset without any postponement and loss is characterized as a liquid instrument and earns less profit. On the other hand, the asset that may get loss when converted to cash before its maturity generally earns some higher profit. These two lead causing a bank dilemma between safety in one side and profitability in another side.

Practically in Islamic Bank, according to Sharia Banking Statistic (SPS) Bank of Indonesia 2008-2011 period, the liquidity problem in Islamic Bank is described by its high $89 \%$ long term investment using murabahah, mudharabah and musyarakah contracts which is unequal to its $71 \%$ short term funding, it is one month time deposit using mudharabah contract. That is proved as the chart below: 


\section{Chart 1}

Islamic Banking Three Most Used Financing Contracts, Total Time

Deposit and One Month Mudharabah Time Deposit (in billion Rupiah)

Source: Processed data from Indonesia Islamic Banking Statistic (SPS), Bank Indonesia.

There are two methods of banking funds allocation based on the thoughts of conventional to manage liquidity, they are pool of funds approach and asset allocation approach (Siamat, 2005a, p. 328), and the practiced one both in Islamic and conventional banks is pool of funds approach (Wibowo, 2012). Pool of funds approach is a method combines all liabilities and treats it as a single fund source (Siamat, 2005a, p. 329), and asset allocation approach is a method treats every liability to its kinds and allocates it as its source (Arifin, 2009, p. 66).

Because the operational systems between Islamic and conventional banks are different, having the different method of banking funds allocation system becomes a must for Islamic bank. But in the fact, both Islamic bank and its rival - conventional bank - practice the same method; they practice pool of funds approach to allocate their funds (Pratiwi, 2012).

The same theme - assets and liabilities management - previous research has done by many researchers. Some of them are Khan and Ahmed (2001) with their research title "Risk Management: an Analysis of Issues in Islamic Financial Industry". The research shows that Islamic Banks face two kinds of risk; the first risk is the same risk as the conventional banks face, such as credit risk, market risk, liquidity risk, and etc. And the second risk is caused by its different and unique assets and liabilities structure. Then Bidabad and Allahyarifard (2008) with their research title "Assets and Liabilities Management in Islamic Banking". The research shows the different approach in assets and liabilities management of Islamic banks is caused by its different method of its accounting method. The research concludes that profit and loss sharing will increase the added value for real sector in economic. Then Ismal (2010) with his research title "The Management of Liquidity Risk in 
Islamic Banks: the Case of Indonesia". The research results three comprehensive and integrated programs in managing liquidity risk based on sharia perspective and standard practice of international banking. The programs are institutional deepening, restructuring liquidity management on the asset and liability sides and revitalizing the usage of the Islamic liquid instruments. Then Htay and Shuib (2011) with their research title "Asset and Liability Management: Comprehensive Study of Conventional and Islamic Banks in Malaysia". The research concludes Islamic Banks in Malaysia is less influenced than its conventional banks by interest rate risk if they use the net interest margin (NIM) method. In the contrary, they will be more influenced by it if they use net interest income (NII) method than its conventional banks. Then Ariffin (2012) with the research title "Liquidity Risk Management and Financial Performance in Malaysia: Empirical Evidence from Islamic Banks". The research aims to analyze the liquidity risk by describing the relation between financial performance and liquidity risk by measuring the return on asset (ROA) and return on equity (ROE) of Islamic Banks in Malaysia.

Those done researches mostly discussing about the liquidity risk, risk management and other themes of the assets and liabilities management. There is no research in the same theme discussing about the funds allocation method based on sharia's thought until this research is done. Pratiwi (2013) said a research can be done to fulfill the unexamined or the nothingness of the previous research. As the statement, this research is done to fulfill the nothingness and the unexamined of the previous research.

Ideally, Islamic banks must have the own method to allocate their funds. Theoretically, the fact that the available methods - pool of funds approach and asset allocation approach - are from conventional systems and thoughts (Pratiwi, 2012), therefore, this research aims to explore the Islamic perspective on those two banking fund allocation methods.

The main used sharia instrument in this research is Al-Qur'an as the first source of sharia law, the verses about Islamic values in muamalah and the tafseer of it. Other used sharia instruments are fiqh special axiom in muamalah, and the history of the prophet Muhammad pbuh and Sahabah which has relation to the financial system, especially in fund allocation.

This research is limited on the discussion of Islamic values in mualamah that stated in some verse of Al-Qur'an, the History of Islam age which has relating to the fund allocation method, and fiqh special axiom. Those Islamic values are the used basic in exploring sharia perspective in the conventional thought of funds allocation method. And the discussion of those two methods and its concept in Islamic bank practice as explained in the main literature of this research.

Hopefully, this research may contribute for both practical and theoretical sectors. In the theoretical sector this research may give some valuable literatures especially in the theme of Islamic assets and liabilities 
management. In the practical sector, the result of this research may guide the Islamic banks in the management of fund allocation method.

The next discussion of this research is literature survey. Then in the next part will be discussed the research methodology. The research finding and discussion will be discussed in the fourth part. The conclusion will be the last discussion.

\section{Literature Review}

\subsection{Methodology Tafser Al-Qur'an}

According to Ayyub (2004) in Al-Faizin (2010), Tafser in epistemology means al-idlah and at-tabyin or clarifying and explaining. In terminology, it is a science of the senses explanation of Al-Qur'an and digging out the law, wisdom, mau'idzah and lesson therein (Yunus, 2002). There are three kinds of tafser according to Ayyub (2004) as AlFaizin's (2010) explanation:

\section{a. Tafser bi Ar-Riwayah or bi Al-Ma'tsur}

It is to interpret Al-Qur'an with Al-Qur'an itself, hadits, or shabah statements. Tafsers such as At-Thabary, As-Samarqandy, Ad-Durr AlMantsur, Ibnu Katsir, Al-Baghawi are classified into this kind of tafser.

\section{b. Tafser bi Ad-Dirayah or bi Ar-Ra'yi}

It is to interpret Al-Qur'an with the thought (ra'yu). The ra'yu or thought means Ijtihad that according to its basic decided principal. It is different from the logical interpretation without any Ijtihad basic principles, it is misled.

According to As-Suyuthi (1988) in Al-Faizin (2010) generally there are four basics should get to those who will interpret Al-Qur'an:

a. To excerpt Prophet Muhammad pbuh and avoid maudhu and dhaif hadits,

b. To take shahabah's opinion. According to mufassir it is such as marfu' hadits,

c. To understand Arabic language grammatically, and

d. To know sharia basic axiom (Al-Ushul As-Syar'iyyah).

Thus not everyone could interpret Al-Qur'an as had been happening so far. They who have not basic principles ijtihad interpret AlQur'an as they want, therefore their interpretation are misled. Tafser such as Al-Jalalain, Al-Baidlawy, Al-Alusy, Al-Ghazin are classified into this kind of tafser (Al-Faizin, 2010).

The kind of tafser $b i A r-R a$ 'yi is to interpret Al-Qur'an with modern sciences, such as astronomy, medical science, economy and management. There are pro and contra to this kind of tafser. According to Al-Qardhawi (2002), Muslim Theologian such as Syaikh Syaltut and Sayyid Quthb are the contra to this tafser, and Imam Ghazali and As- 
Suyuthi are the pro to this tafser. Imam Ghazali said, globally whole sciences are included Allah's deed and nature. Whereas Al-Qur'an explains the substance, deed and nature of Allah, the sciences nature are not the last. In Al-Qur'an there is only global sign about the sciences.

There are many things to be noticed to interpret Al-Qur'an with the modern sciences according to Al-Qardhawi (2002) as explained by Al-Faizin (2010):

a. To hold on scientific fact and not to hypothesis.

b. This is an important thing, if Al-Qur'an is interpreted by a hypothesis, then the interpretation becomes changeable following the hypothesis.

c. To avoid self-pressuring to understand nash

d. It is forbidden to force an Al-Qur'an nash with the meaning that will be concluded. It is should take some means that are suitable to the language and the available nash redaction structure.

e. To avoid blaming people are stupid

It is never to think the previous Muslim or even Ulama are stupid because they could not interpret what it has just interpreted early.

c. Tafser bi Al-Isyarah or Tafser Al-Isyari

It is the interpretation done by Tashawwuf to dig out Al-Qur'an wisdom. Some Ulama' tolerates to do this tafser and some forbids. Tafser An-Nibury and Tafser Ruhul Ma'any are classified into this kind of tafser.

\subsection{Al-Qur'an Verses of Islamic Values in Muamalah}

Below are the verses of Al-Qur'an as the used instruments to explore the perspective of Islamic values in muamalah on the conventional thought of bank fund allocation methods, pool of funds approach and asset allocation approach. From those verses, it will be taken the values that would be considered in analyzing those two methods.

\subsubsection{Amanah Transaction in Al-Qur'an}

One of Al-Qur'an verses about Islamic values in muamalah Amanah transaction - is in surah An-Nisa at $58^{\text {th }}$ verse (Bisyri, 2013):

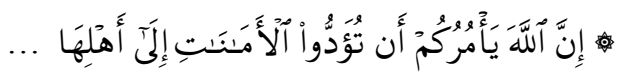

"Verily! Allah commands that you should render back the trusts to those, to whom they are due"...

2.1.2. The Source of Property Ownership in Al-Qur'an (Syaamil AlQur'an, 2010) 
The property that someone owned should clear its ownership. Allah said in Al-Baqarah at $188^{\text {th }}$ verse about the source of property ownership:

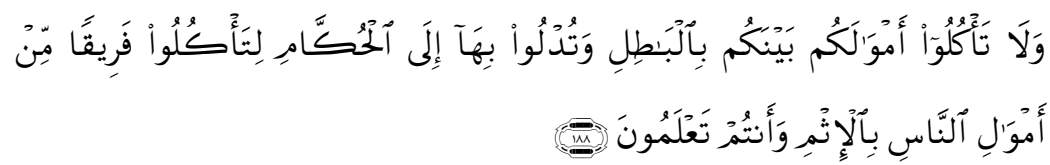

“And eat up not one another's property unjustly (in any illegal way), nor give bribery to the rulers (judge before presenting your cases) that you may knowingly eat up a part of property of others sinfully."

2.1.3. The Evidence in Transaction in Al-Qur'an (Syaamil Al-Qur'an, 2010)

Allah said in Surah Al-Baqarah at $283^{\text {rd }}$ verse about never hide the evidence:

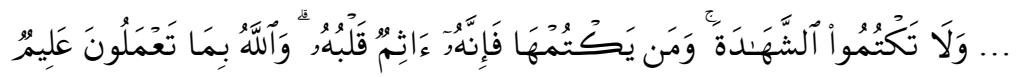

"And conceal not the evidence for he, who hides it, surely his heart is sinful. And Allah is All-Knower of what you do."

2.1.4. A Fair Wight and Measure of Transaction in Al-Qur'an (Syaamil

Al-Qur'an, 2010)

Being fair in fulfilling weight and measure in transaction in muamalah is one of Islamic values. Allah said in Surah Hud at $85^{\text {th }}$ verse:

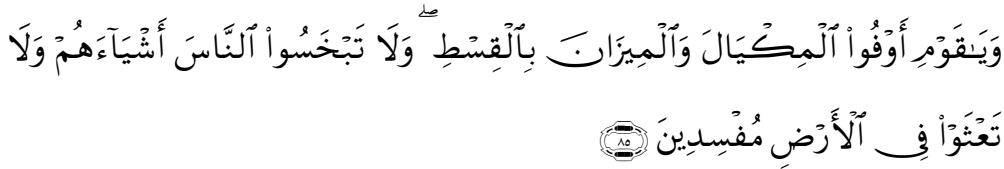

"And O my people! Give full measure and weight in justice and reduce not the things that are due to the people, and do not commit mischief in the land, causing corruption."

2.2 Operational Principle of Islamic Bank

The operational principle of Islamic banks should free from the things below (Soemitra, 2009):

1. Maysir or speculation or gambling. It is lottery fate and be chancy. Word maysir in Al-Qur'an is repeated 44 times in AlBaqarah 219 and Al-Maidah 90-91,

2. Gharar or deceiving or uncertainty. It is deceiving transaction of someone's wealth. Word gharar and its derivation are repeated 27 times in Al-Qur'an. Two of it are in Surah Al-Anfal 49 and Ali-Imran 185,

3. Haram or forbidden. Word haram is repeated 83 times in AlQur'an,

4. Riba or interest. It is refund the loan funds with some required rate fund. Word riba is repeated 20 times in Al-Qur'an. In Surah Al-Baqarah 270-280, Ali-Imran 130 and An-Nisa 160-161, and 
5. Bathil or void or illegal. It is kind of decreasing the weight and etc.

\section{Research Methodology}

\subsection{Research Scope}

The aim of this research is to reveal Islamic perspective on the conventional thoughts of banking fund allocation method. Islamic values in muamalah that are implied in some verses in Al-Qur'an, Fiqh Special Axiom in muamalah and history of the financial system in the Prophet Muhammad pbuh and Shabah eras are the used sharia instruments in this research to achieve the research objective.

\subsection{Research Type}

The type of this research is descriptive research with a qualitative approach that leaned on Islamic thoughts (Hakim \& Handoko, 2009, p.8). The aim of a descriptive research is to describe the facts of the analyzed object actually and accurately (Nazir, 1988, p.63). And qualitative research data is stated verbally and analyzed without using any statistic tools (Sangadji \& Sopiah, 2010, p. 21).

\subsection{Research Technique}

The technique that used in this research is qualitative technique; one of its functions is to understand the sensitive issues and to do some evaluation (Moleong, 2010, p. 7). The technique of this research is first done by understanding and exploring the data, from these steps, the analyzed problem is discovered. After the analyzed variables is understood then the problem is solved by writing it descriptively. The next step to solve the problem is done by study literature; it's done by searching for the verses of Al-Qur'an about the Islamic values in muamalah that relating to the research problem. After those verses are found, the tafsers of those verses are discussed and interpreted to look for the solution. Besides that, another solution is also searched by discussing the history of Prophet Muhammad pbuh and Caliph Umar bin Abdul Aziz.

3.4 Data Collecting and Analysis Technique

The collecting data technique that used in this research is survey literature technique. The aim of it is to make sure that there is no important variable in the past that found repeatedly influencing the overcome problems (Sekaran, 2006, p. 82-83).

The data analysis of this research is done by content analysis method. It is a method that used for normative research (Bisri, 2001, p.60). It is meant as a technique to interpret and identify the characteristic of a command specifically, objectively and systematically (Stemler, 2001).

The first step in analyzing data is done by studying the liquidity problem that absolutely happen in both Islamic and conventional banks. 
From the main literature, it is found that to face the liquidity problem there are two methods in allocating funds, it is pool of funds approach and asset allocation approach. Those two methods are from conventional thought and pool of funds approach is practiced in Islamic banks.

It is important to solve the problem using the Islamic instruments because Islamic bank has sharia in guiding its operation. Then the next step is done by study literature searching for the verses of Al-Qur'an about Islamic values in transaction, this is done because what there in the two methods is muamalah process. Those steps are done in order to gain the scientific truth (Narbuko dan Achmadi, 2004, p. 6).

\section{Research and Discussion}

There is no Al-qur'an verse which mentions the rule of bank fund allocation method. But, what happens in the fund allocation method in a bank is muamalah process between bank management and its costumer. And for that case, Islam has values and rules that should be done in muamalah. So, the next point will be discussed about the tafsers of AlQur'an verse which relate to the Islamic values in muamalah. Other used sharia instruments are fiqh axiom special in muamalah and the history of financial system in Prophet Muhammad pbuh and Shahabah eras. Then it will be discussed and analyzed about the two conventional thought of banking fund allocation method according to sharia instruments that discussed in the previews. The last point will be discussed about the more agreeable method to all used sharia instruments that have been discussed before.

\subsection{Tafser of Al-Qur'an Verses about Islamic Values in Muamalah}

In this point will be discussed the tafser of Surah An-Nisa 58, the verse about amanah transaction, Surah Al-Baqarah 188, the verse about the source of property ownership, Surah Al-Baqarah 283, the verse about the evidence in transaction and Surah Hud 85, the verse about being fair in fulfilling weight and measure in transaction. After the tafser discussion, in its end subchapter, it will be taken a lesson from each tafser and will be interpreted to solve the problem.

\subsection{Tafser Surah An-Nisa Verse 58 for Amanah Transaction}

In that verse Allah commands to deliver amanah to those who have the right. Amanah in that verse means something that is trusted to be done well by someone believed. Word amanah by the mean is wide including Allah's amanah to His Servant, people's amanah to their peer including to themselves. Allah's command to do amanah between people to the others is doing amanah perfectly, that means neither put it off nor delay it. That amanah is including trusteeship, property, secret, and order that only Allah who knows it (Ibnu Sa'di Tafser).

From the verse, it can be taken a lesson that amanah is one of Islamic values in muamalah that Allah commends; it means doing amanah is very important to achieve a best muamalah. Connecting it to 
the Islamic banking practice, this case is in funds allocation, doing amanah can be actualized by allocating funds as its source and characteristic.

\subsection{Tafser Surah Al-Baqarah Verse 188 for Source of Property Ownership}

Narrated Ali Bin Abi Thalib from Ibnu Abbas that there was someone owning the property but he did not have any ownership evidence of his property. Then he manipulated that property to a judge while he realized it was not his own and he knew it was a sinful. Some Salaf Ulama said not to report a wrong-known issues (Ar-Rifa'i, 1989).

From the verse, it can be taken a lesson that an ownership evidence of property source is very important to be had. For Islamic banks practice, being clear in the source of allocated funds will avoid some sharia forbidden transactions like gharar and etc.

\subsection{Tafser Surah Al-Baqarah Verse 283 for Evidence in Transaction}

In that verse, Allah orders to write every non-cash transactions and behave justly for every writer. This is done to avoid some predisposed situation in postponed muamalah such as being forgotten, neglected, mistaken and etc, and also to prevent the behavior of nonamanah people in muamalah who does not afraid of Allah's warning. In that verse Allah also permits muamalah without any evidence only for those pious people (As-Sa'di, 2007, p. 477).

One of Islamic values in muamalah from the verse is doing a better notation in muamalah. Connecting it to Islamic banks muamalah process, being identified the source of allocated funds is one of its actualization.

\subsection{Tafser Surah Hud Verse 85 for Being Fair in Fulfilling Weight and Measure}

In that verse Allah explains the necessity that becomes a must in fulfilling someone rights in muamalah. It is being honest to complete someone's right in weight and measure (Basyir, 2011, p. 121). In that verse, Allah forbids totally to act dishonestly by decreasing someone's right in the weight and measure (As-Sa'di, 2007, p.551). From the verse, being fair is what should be done in muamalah and it is one of amanah actualization.

\subsection{Fiqh Special Axiom in Muamalah}

According to Djazuli (2006, p. 130-137) there are twenty fiqh special axioms in muamalah, and the used one in this research is axiom

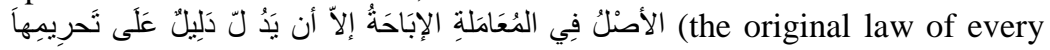


muamalah is permitted to do except if there is verse that forbids it) (Djazuli 2006, p. 130).

The basic thought of using this axiom is the always MUI (Indonesia Ulama Council) of using this axiom in its issued fatwa. The axiom means all muamalah transaction such as trading, leasing, pawning, cooperating (mudharabah and musyarakah), and etc are permitted to do except damaging muamalah such as gambling, loaning with interest, defrauding, and etc, that Allah has forbidden in Al-Qur'an clearly.

History of Financial System in the Prophet Muhammad pbuh Era

Even though there was no modern banking activity as nowadays in the Prophet Muhammad pbuh era, today banking practice such as saving and etc. has been practicing since that era (Karim, 2007). Al-Amin that titled to Prophet Muhammad pbuh was because of his honesty that he was believed by Medina people to accept such property saving.

It's narrated in the end of the day before migrating to Medina, Prophet Muhammad pbuh asked Ali bin Abi Thalib for returning back all the saving property to the owners (Hamoud, 1985). From the history, amanah behavior is the lesson that can be taken to be applied in muamalah, especially in the banking funds allocation method.

\section{History of Financial System in Muawiyah Era}

It was Umar bin Abdul Aziz in Muawiyah era who known for his devotion and justice. Even though in this era Islam has decreased, his leadership has taken Muslim into the unforgettable era prosperity of Muslim. In His era, he distributed national income justly so it deleted the poverty until it couldn't be found people who accept zakah or mustahik (Rivai \& Veithzal, 2008, p. 74-75). From the history, it is amanah behavior can be taken to be applied in muamalah, especially for the method of banking fund allocation.

\subsection{Pool of Funds Approach Overview}

Pool of funds approach was used at the beginning of banking era after the great depression. The method in 1930s has undergone liquidity crisis that caused by commercial banks manager more emphasizing the safety than profitability in the method of portfolio selection. The weaknesses of this method are; first, it doesn't provide relative composition in the credit provision. Second, it doesn't have a base to estimate the need of liquidity. Third, there is no available information of consistency the saving deposits volatility. Fourth, it ignores the liquidity provided by credit portfolio from interest payment. And fifth, it ignores the fact of bank ability to earn much money is what will make a bank survive. The strength of the method is the calculation of cost of funds is simpler and less complex (Graddy \& Spencer, 1990, p. 270-271).

The method treats whole source of bank funds as a single fund and allocates it without considering its source (Siamat, 2005a, p. 329). The method is done by making standard liquidity such as deciding the 
amount and time of the need of money. Generally, the standard is based on the opinion, estimation, intuition, and experience of the upper management (Graddy \& Spencer, 1990, p. 273). Below is the method picture:

Picture 4.1 Conventional Thought of Pool of Funds Approach

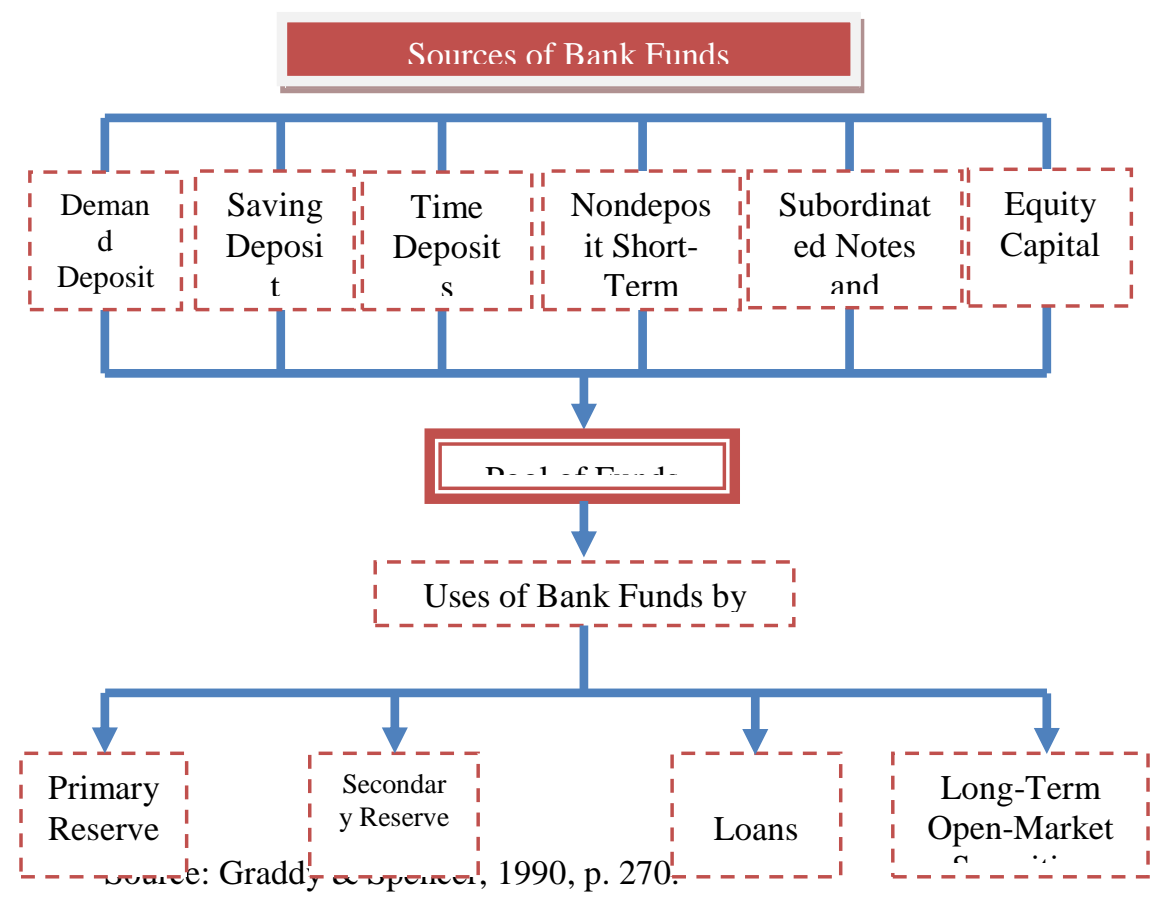

Picture 4.1 above describes the method of pool of funds approach of the conventional thought. It treats the sources funds from demand deposits, saving deposits, time deposits, non-deposit short-term borrowing, subordinated notes and debentures, and equity capital into the single source fund and allocates it to the banks priority.

First step of fund allocation in this method is made for the need of primary reserves, such as cash money, deposit in central bank and other banks and clearance documents. A bank is required by the law to keep a specified percentage of total saving deposits, the cash money is needed in daily operational bank, and the leftover of liquidity will lead to the unexpected demand for loan are the factors of why primary reserves in a bank becomes a highest priority. The next fund allocation in this method is made for secondary reserves, such as short term securities for less than 1 year and long term securities for less than 3 years. Secondary reserve can increase bank's profit. And the last fund allocation is this method is for loan. Loan is main business for whole banks (Graddy \& Spencer, 1990, p.272). 
The practice of pool of funds approach method in Islamic bank would be described as below according to Arifin (2009, p.66) explanation:

Picture 4.2 Pool of Funds Approach in Islamic Banks

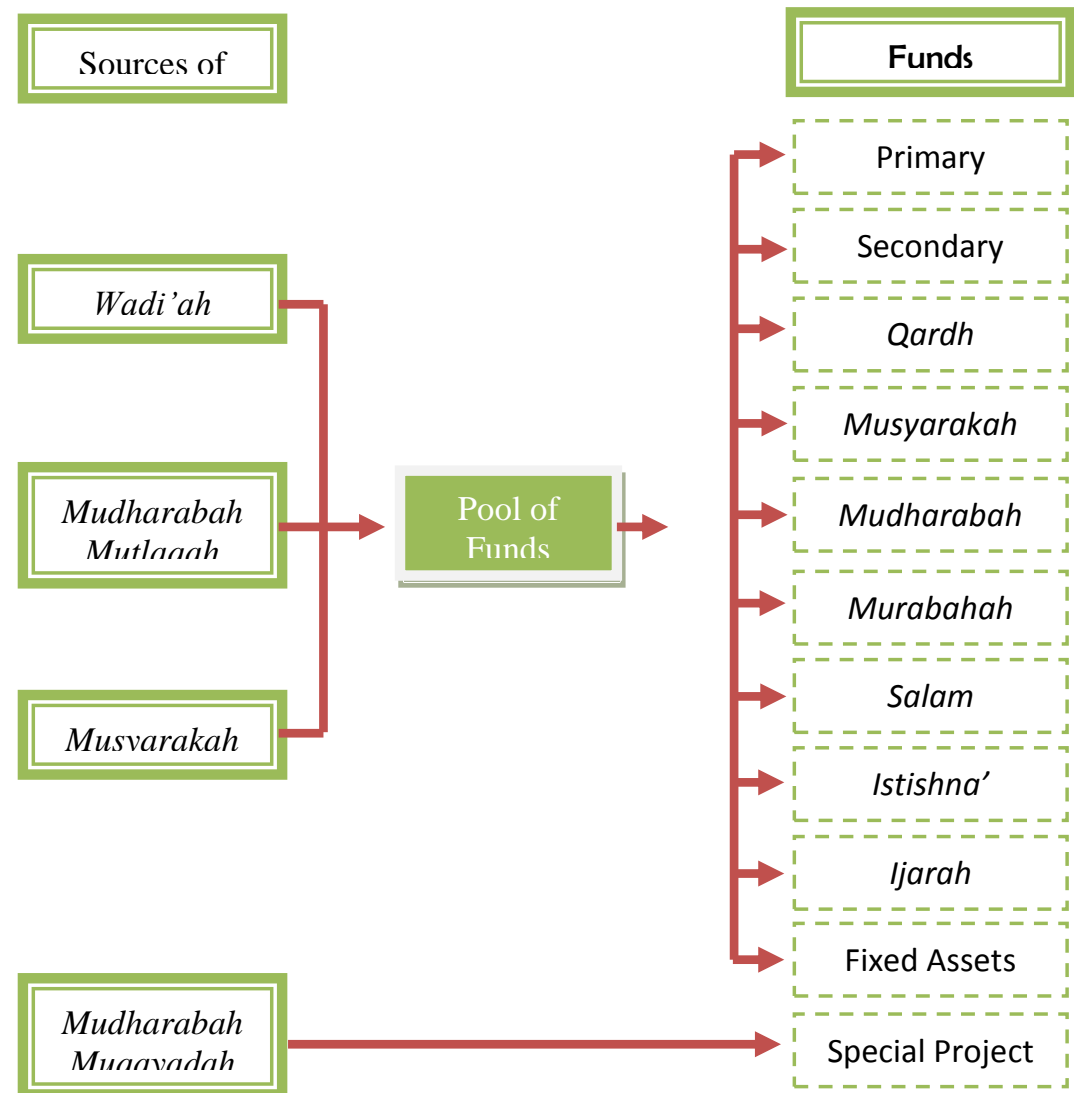

Source: Arifin, 2009, p. 66.

Picture 4.2 above explains the implementation of pool of funds approach in Islamic bank. It has the same basic theory as the conventional one. The differences between these two methods are; first, Islamic bank has some sharia contracts in both funding and lending activity and not in conventional bank. The method treats the collected fund from wadi'ah, mdharabah mutlaqah and musyarakah into single source of fund and allocates it to primary reserve, secondary reserve and other sharia lending contracts such as murabahah, ijarah and etc. Second, Islamic bank has mudharabah muqayyadah contract which requires the use of its funds is 
determined by costumer, so its fund is allocated to required-special project.

\subsubsection{Pool of Funds Approach in the Perspective of Islamic Values in Muamalah}

In point 4.5 , it has discussed that pool of funds approach method had ever undergone liquidity crisis in 1930s. If a method of muamalah had proved its damage and left mudharat (disadvantage), reapplying that method into sharia, in this case in Islamic bank practice, it should be analyzed deeply using sharia instruments. In this point, it will be discussed the pool of funds approach method in Islamic bank in the perspective of Islamic values in transaction.

As the picture of conventional thought of pool of funds approach in 4.1 , the picture describes the conventional method in allocating fund by pooling the fund into single source fund, and in picture 4.2, it is the pool of funds concept in Islamic bank that adapted from conventional one. However, Islamic bank has sharia as basic law in its operation.

There is no problem in conventional thought to allocate fund without noticing its source or its characteristic, all done is about business. But it's going to be different for Islamic bank; sharia law will lead its operation.

\subsubsection{Pool of Funds Approach in the Perspective of Surah Al- Baqarah 188}

Applying pool of funds approach in Islamic bank makes some unsuitable practices to the sharia law. Picture 4.2 describes it. The example would be like this; qardh is an Islamic-social instrument which is forbidden to take any required additional fund from it. How much money is borrowed by qardh contract is how much money is paid back. And in pool of funds approach, the funds that are allocated could not be identified its source.

Being identified the source of property is one of the lesson of Islamic values in transaction from Al-Baqarah 188 as explained in point 4.1.2. Therefore, pool of funds approach method which could not identify the source of funds is not suitable to the values of Islamic transaction of that verse.

\subsubsection{Pool of Funds Approach in the Perspective of Surah An-Nisa 58 and History of Prophet Muhammad pbuh and Caliph Umar bin Abdul Aziz}

As it has described in picture 4.2, pool of funds approach in Islamic banking could not accomplish sharia contracts. That picture 
makes this clear. For example, the first contract in funding is wadi'ah or mudharabah, then as the process of pool of funds, the funds can't be identified what the contract has agreed for it. This means, pool of funds approach method couldn't complete the contracts and it leads to nonamanah muamalah. Amanah is one of Islamic values in muamalah as it taught in An-Nisa 58 as explained in point 4.1.1. Being amanah in allocating bank funds can be actualized by doing it as its source. The lesson in muamalah from the history of Prophet Muhammad pbuh and Caliph Umar bin Abdul Aziz as explained in point 4.3 and 4.4 also doing amanah. And as it has explained, this method does it nothing.

\subsubsection{Pool of Funds Approach on the Perspective of Surah Hud 85 and Al-Baqarah 283}

As it has explained in point 4.5.1.2 above that this method could not accomplish the agreed contracts. Then, if it couldn't be completed, how weight and measure are fulfilled and be fair on it. Moreover, its being unable to complete the transaction proves this method could not do a better notation, than it leads to unable to provide the evidence of transaction. Being fair in fulfilling weight and measure as explained in point 4.1.4 and doing a better notation in muamalah in point 4.1.3 are two of Islamic values in muamalah from surah Hud 85 and Al-Baqarah 283, and the method is unable to fulfill those values.

\subsubsection{Pool of Funds Approach in the Perspective of Fiqh Special Axiom in Muamalah}

Fiqh special axiom in point 4.2 explains that the original law of muamalah can be done except if there is a verse forbids it. Even though the verses and other instruments that have explained above in point 4.5.1.1, 4.5.1.2, and 4.5.1.3 are not explicitly forbid the pool of funds approach method, but as it has explained the method couldn't fulfill the Islamic values that taught on those verses and that the other instruments, so the method is not what on this axiom meaning. Therefore, the axiom could not use to legalize the usage of the method.

\subsection{Asset Allocation Approach Overview}

This asset allocation approach is also known as conversion of funds approach. It is a correcting method for the previous one, pool of funds (Siamat, 1995b). The competition of non-bank institution started in 1950s and changed commercial bank liability structure. The innovation of source funds such as negotiable certificates of deposits, Eurodollars, repurchase agreements, and capital notes had made pool of fund approach became harder to apply. By those innovations, it became unrealistic to treat the whole sources of funds as a single source. In fact, every source has its own characteristic and unique volatility. Besides that, the continuously rising trend of rate in stock market made reserve 
management more efficient. Commercial bank managers responded the phenomena by implementing this method (Graddy \& Spencer, 1990, p. 273).

What makes this method different from the previous one is its treating every source of fund as its characteristic (Graddy \& Spencer, 1990, p. 273). Basically, this method explains the unrealistic of treating the whole source of bank funds as a single source, because every source of fund has its nature. Therefore, in its allocation priority, every source of funds is treated individually as its source and characteristic. In this method, funds which have higher turnover is allocated for primary and secondary reserves and funds which have lower turnover is allocated for loan and long term asset (Siamat, 1995b, p. 87-88). Below is the picture of asset allocation approach method:

Picture 4.3 Conventional Thought of Asset Allocation Approach

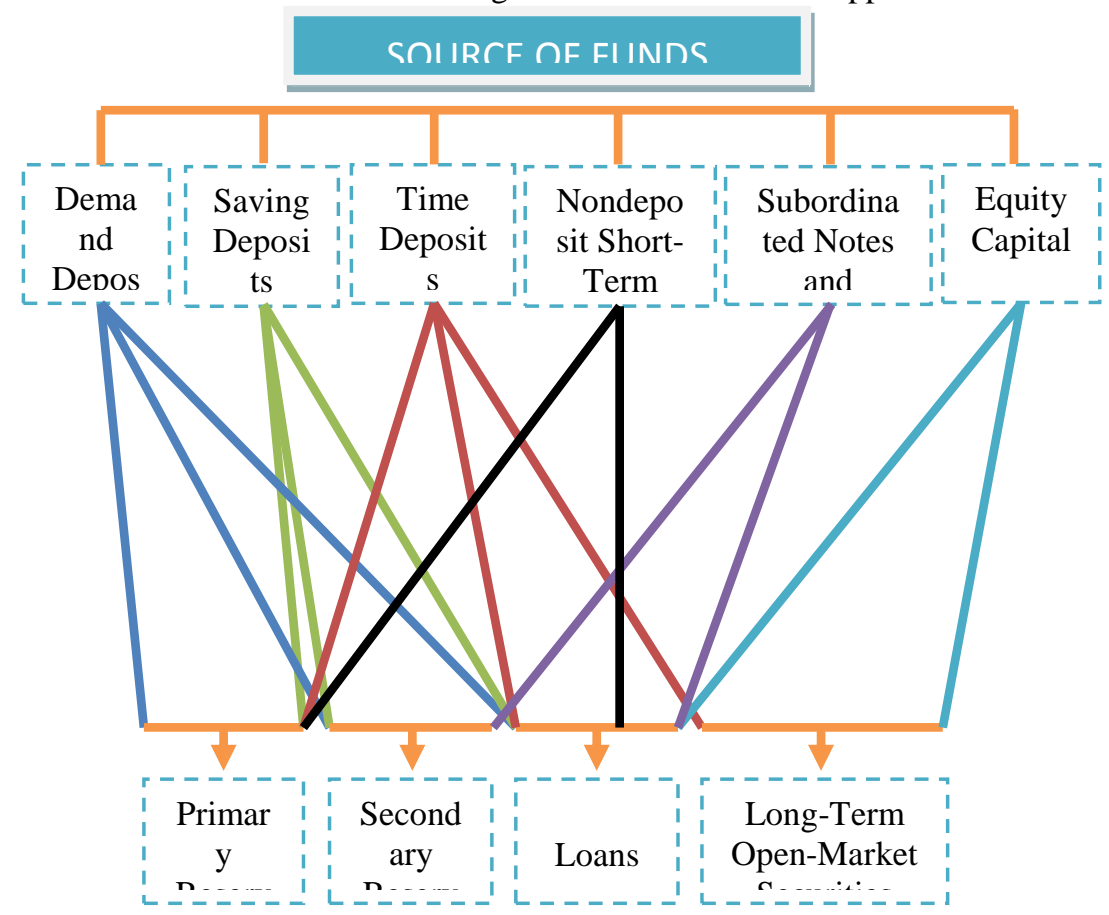

Source: Graddy \& Spencer, 1990, p. 274

From picture 4.3 above, asset allocation approach treats the funds from demand deposits, saving deposits, time deposits, non-deposit short term borrowing, subordinated notes and debentures, and capital equity into individual source of funds. For example, capital equity which has long term turnover is allocated to long-term open market securities and loans. Other examples, demand deposits which can be withdrawn anytime by costumers is allocated for operational bank. Then saving deposits, 
even it has same characteristic to demand deposits, the fund of this source is disposed to be longer than demand deposits, because many people are saving for future needs. This method focuses on the classified liability into the time of maturity and the withdrawn potential, and asset structure is based on the source of funds structure (Riyadi, 2006, p. 26-27).

The strength of this method is its taking over the liquidity into profitability. This method makes the average of liquidity reserves of bank decreasing, so the allocated funds for loan or marketable securities is bigger and more earning profit. And the weakness is its deciding the needs of liquidity based on the estimation of saving turnover. As a result of that the profit may decrease because the surplus estimation of liquidity needs. (Siamat, 2005a, p. 332). The method in Islamic bank can be illustrated as below:

Picture 4.4 Asset Allocation Approach for Islamic Bank

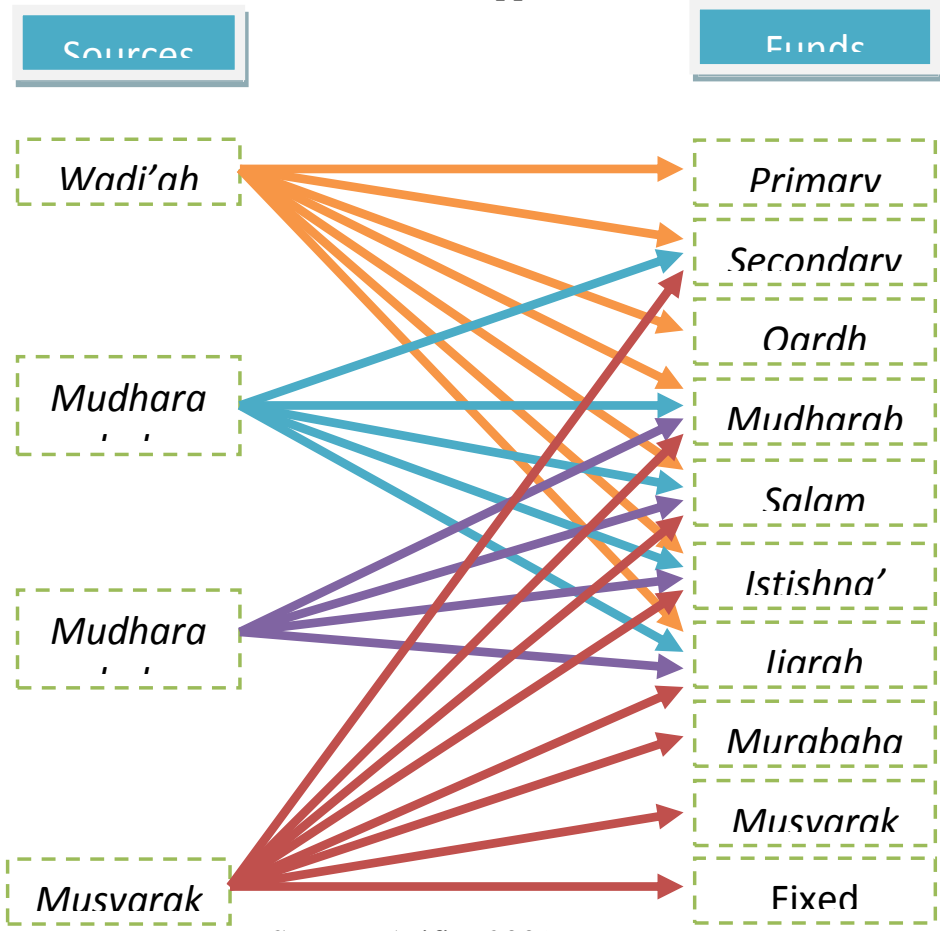

Source: Arifin, 2009, p. 67.

That picture 4.4 above describes asset allocation approach concept in Islamic banks. It treats the funds clearly by allocating it as its source. However, it is different from the conventional one, because Islamic bank has a specific and detail contracts in its funding, so the concept implementation of this method becomes different.

4.8.1. Asset Allocation Approach in the Perspective of Islamic Values in Muamalah 
As it has explained in point 4.6 , this method is a correcting method for the previous one. It means this method is better than the previous one. It is explained in picture 4.4; the allocated funds of this method can be identified its source, for example, funds from wadi'ah is allocated to primary reserve, secondary reserve, qardh, murabahah, salam, istishna and ijarah. More explaination will be discussed in points below:

\subsubsection{Asset Allocation Approach in the Perspective of Surah Al- Baqarah 188}

In point 4.1.2, it has explained that, the lesson of Islamic values in muamalah as taught in Al-Baqarah 188 is being identified the source of property. The way of this method in treating every source of funds as it has explained in point 4.6, is suitable to the Islamic values of that verse; the whole sources of allocated funds can be identified as described in picture 4.4. Therefore, this method is suitable to the Islamic values in muamalah as it taught in Al-baqarah 188.

\subsubsection{Asset Allocation Approach in the Perspective of Surah An- Nisa 58 and History of Prophet Muhammad pbuh and Caliph Umar bin Abdul Aziz}

In picture 4.4 , it can be seen that asset allocation approach completes every agreed contracts. It is proved by its being identified the allocated funds. For example, contracts mudharabah in funding is allocated also to mudharabah and other contracts in lending. Being able to complete the contracts means this method does amanah. As it has explained in point 4.1.1, amanah is one of Islamic values in muamalah that taught in An-Nisa 58. Being amanah in allocating bank funds can be actualized by doing it as its source. The lesson in muamalah from the history of Prophet Muhammad pbuh and Caliph Umar bin Abdul Aziz as explained in point 4.3 and 4.4 also doing amanah. And this method does it.

\subsubsection{Asset Allocation Approach on the Perspective of Surah Hud 85 and Al-Baqarah 283}

In this method all contracts are done completely as it's described in picture 4.4. It means that this method could fulfill the weight and measure. Being able to complete the contracts, this method is also indicated could provide a better notation, another poof is its being identify the source of allocated fund. Being fair in fulfilling weight and measure as explained in point 4.1.4 and doing a better notation in muamalah in point 4.1.3 are two of Islamic values in muamalah from surah Hud 85 and Al-Baqarah 283, and this method is able to do those values.

\subsubsection{Asset Allocation Approach on the Perspective of Fiqh Special Axiom in Muamalah}


As it has explained in point 4.2, the original law of muamalah can be done except if there is a verse forbids it. Even there is no verse explicitly forbid or allow this method - asset allocation approach - in muamalah, but as it has explained in point 4.6.1.1, 4.6.1.2 and 4.6.1.3, that the method does the Islamic values in those Islamic instruments. Therefore, this method is suitable to the meaning of this axiom.

\subsection{The Most Agreeable Method to the Islamic Perspective}

In this point will be discussed which one between two conventional methods of fund allocation - pool of funds approach and asset allocation approach - is more agreeable to Islamic instruments that have used in this research.

In the discussion of points $4.1 .1,4.1 .2,4.1 .3$ and 4.1 .4 , it has explained that the used sharia instruments to reveal the perspective of Islamic values in muamalah are doing amanah as it taught in An-Nisa 58, history of Prophet Muhammad pbuh and Caliph Umar bin Abdul Aziz, being identified the source of owned property as it taught in Al-Baqarah 188 , being fair in fulfilling weight and measure in transaction as it taught in Hud 85 and being better in noticing transaction as it taught in AlBaqarah 283.

As it has explained in point 4.5 that pool of funds approach has undergone liquidity crisis in 1930s. Its treating whole funds into single source method makes pool of funds approach could not complete all agreed contracts in its sharia application as explained in picture 4.2.

As it has explained in point 4.6 that asset allocation approach is a correcting method for pool of funds approach. Its being identified every allocated fund and as it's described in picture 4.4 that asset allocation approach treats the whole contracts completely.

Therefore, as in the discussion of points 4.5.1.1, 4.5.1.2, 4.5.1.3 and 4.5.1.4 and the discussion of points 4.6.1.1, 4.6.1.2, 4.6.1.3 and 4.6.1.4 can be concluded that the most agreeable method to the instruments of shariah that used in this research is asset allocation approach.

\section{Conclusion and Recommendation 5.1 Conclusion}

The aim of this research is to explore the Islamic perspective on the conventional thought of banking fund allocation method. The perspective of Islam that used in this research is Islamic values in muamalah that taught in used sharia instruments of this research. The main used sharia instrument in this research is Al-Qur'an verses which relating to the values in muamalah, they are An-Nisa 58, Al-Baqarah 188, Hud 85 and 
Al-Baqarah 283. Other used sharia instruments are history of Prophet Muhammad pbuh and Caliph Umar bin Abdul Aziz and Fiqh special axiom in Muamalah.

Islamic value in muamalah as taught in An-Nisa 58 and history of Prohet Muahmmad pbuh and Caliph Umar bin Abdul Aziz is doing amanah. Pool of funds approach which treats every whole single source could not complete the agreed contracts, while asset allocation approach treats every source and complete the agreed contracts. Completing the agreed contracts means doing amanah, therefore, asset allocation is more agreeable method to this instrument than pool of funds approach.

Islamic value in muamalah as taught in Al-Baqarah 188 is being identified the source of owned property. Pool of funds approach which pools whole source into single source could not identify the source of allocated fund, while asset allocation approach could identify every source of allocated funds; therefore asset allocation is more agreeable method to this instrument than pool of funds approach.

Islamic values in muamalah as taught in Hud 85 and Al-Baqarah 283 is being fair in fulfilling weight and measure and doing a better notation in transaction. Pool of funds which treats whole source of funds into a single source could not do a better notation, because it could not identify the source of allocated funds. While asset allocation approach treats every source of funds into individual fund and able to identify the source of allocated funds makes this method able to fulfill the weight and measure and do a better notation. Therefore, asset allocation approach is more agreeable method to these two instruments than pool of funds approach.

\subsection{Recommendation}

It is recommended for Islamic banks to practice asset allocation approach method. As it has explained, it is a correcting method for the previous one and it is more agreeable method to the Islamic values in muamalah.

Also it is recommended for the next researcher to do comparative research which comparing the practice of funds allocation method in Islamic bank in Indonesia and Islamic bank in other countries. From that research can be found which Islamic bank of the country is more agreeable to Islamic values.

\section{BIBLIOGRAPHY}

Al-Faizin, A.W. (2010, LKTEI FOSSEI-IX). Entrepreneurship Values and Business Strategy in The Perspective of Surah Quraisy. Bogor: STEI Tazkia. 
Arifin, Z. (2009). Dasar-Dasar Manajemen Bank Syariah (Edisi Revisi). Jakarta: Azkia

Publisher.

Ariffin, N. M. (2012). Liquidity Risk Management and Financial Performance in Malaysia: Empirical Evidence from Islamic Banks. Aceh International Journal of Social Sciences, 1. 2, 6875.

Ayyub, H. (2004). Al-Hadits fil Ulum Al-Qur'an wa Al-Hadits. Kairo: Daar Al- Salam.

Bisri, C. H. (2001). Penuntun Penyusunan Rencana Penelitian dan Penulisan Skripsi Bidang Ilmu Agama Islam. Jakarta: PT Raja Grafindo Persada.

DeLorenzo, Y. T. (2004). Shari'a Supervision of Islamic Funds. London: Euromoney Books. Islamic Asset Management: Forming the Future for Shari'a-Compliant Investment Strategies. 12-32.

Hakim, A. \& Handoko, L.H. (2010, SEBI Jurnal). Kritik Terhadap Produk Deposito Fixed Return: Basis Commodity Murabahah Product (CMP). SEBI Islamic Economics and Finance Jurnal, 03.1, 5-34.

Graddy, D.B \& Spencer, A.H. (1990). Managing Commercial Banks: Community, Regional, and Global. New Jersey: PRENTICE-HALL. INC.

Htay, S.N.N. \& Shuib, S.S.B. (2011). Asset and Liability Management: Comparative Study of Conventional and Islamic Banks in Malaysia. Kuala Lumpur: IIUM. Paper presented at the International Islamic Banking, Finance and Investment Conference, 19-20 December 2011, Hotel Istana, Kuala Lumpur, Malaysia.

Ismal, R. (2010). The Management of Liquidity Risk in Islamic Banks: The Case of Indonesia. Durham E-Thesis. United Kingdom: Durham University.

Khan, T. \& Ahmed, H. (2001). Risk Management: an Analysis of Issues in Islamic Financial Industry. Occasional Paper No. 5. Jeddah: Islamic Development Bank.

Moleong, L. J. (2010). Metodologi Penelitian Kualitatif. Edisi Revisi. Bandung: PT. Remaja Rosdakarya.

Narbuko, C. \& Achmadi, A. (2004). Metodologi Penelitian: memberikan Bekal pada Mahasiswa Tentang Metodologi Penelitian Serta Diharapkan Dapat Melaksanakan Penelitian dengan Langkah-Langkah Benar . Jakarta: PT. Bumi Aksara.

Nazir, M. (1988). Metode Penelitian. Jakarta: Ghalia Indonesia.

Obaidullah, M. \& Wilson, R.J.A. (2005). Risk Sharing and Management in Infrastructure Financing: an Islamic Evaluation. 19-48. Kuala Lumpur: International Islamic University of Malaysia. Studies in Islamic Banking and Finance in the 21st Century: Theory and Practice.

Qordlawi, Y. (2002). Fatwa-Fatwa Kontemporer (Jilid 3). Jakarta: Gema Insani Press. 
Sangadji, E.M. \& Sopiah. (2010). Metodologi Penelitian: Pendekatan Praktis dalam Penelitian. Yogyakarta: Penerbit ANDI.

Sekaran, U. (2006). Research Methods for Business. (4th edition). Jakarta: Salemba Empat.

Siamat, D. (2005a). Manajemen Lembaga Keuangan: Kebijakan Moneter dan Perbankan. (Edisi Kelima). Jakarta: Lembaga Penerbit Fakultas Ekonomi Universitas Indonesia.

Siamat, D. (1995b). Manajemen Lembaga Keuangan. Jakarta: Intermedia.

Soemitra, A. (2009). Bank dan Lembaga Keuangan Syariah. Jakarta: Kencana Prenada Media Grup.

Stemler, S. (2001). An Overview of Content Analysis. Practical Assessment, Research \& Evaluation 7. (http://PAREonline.net/getvn.asp?v=7\&n=17).

Syaamil Al-Qur'an. (2010). Al-Qur'anulkarim: Terjemah Tafsir per Kata. Bandung: Sygma Publishing.

Thijs, J. P. M. M. (2010). Risk Management in Islamic Bank. Malaysia: Bank Islam Malaysia Berhad.

Rivai, H. V. \& Veithzal, A. P. (2008). Islamic Financial Management: Teori, Konsep dan Aplikasi: Panduan Praktis untuk Lembaga Keuangan, Nasabah, Prkatisi dan Mahasiswa. Jakarta: RajaGrafindo Persada.

Wibowo, H. (2012). Personal Interview. STEI SEBI. (hendro.wibowo83@gmail.com)

Yunus, M. K. (2002). Dirasat fi Ushul Al-Tafsir. Tharabulis: Kuliyyah Al-Da'wah Al- Islamiyyah. 